\title{
Effects of glyphosate-based herbicides and their active ingredients on earthworms, water infiltration and glyphosate leaching are influenced by soil properties
}

Johann G. Zaller ${ }^{1 *} \mathbb{D}$, Maureen Weber ${ }^{1}$, Michael Maderthaner ${ }^{1}$, Edith Gruber ${ }^{1}$, Eszter Takács² ${ }^{2}$ Mária Mörtl², Szandra Klátyik², János Győri ${ }^{3}$, Jörg Römbke ${ }^{4}$, Friedrich Leisch ${ }^{5}$, Bernhard Spangl ${ }^{5}$ and András Székács ${ }^{2}$

\begin{abstract}
Background: Glyphosate-based herbicides (GBHs) are among the most often used pesticides. The hundreds of GBHs used worldwide consist of the active ingredient (Al) glyphosate in form of different salts, possibly other Als, and various mostly undisclosed co-formulants. Pesticide risk assessments are commonly performed using single Als or GBHs at standard soil conditions without vegetation. In a greenhouse experiment, we established a weed population with common amaranth (Amaranthus retroflexus) to examine the effects of three GBHs (Roundup LB Plus, Roundup PowerFlex, Touchdown Quattro) and their corresponding Als (salts of glyphosate isopropylammonium, potassium, diammonium) on the activity and physiological biomarkers (glutathione S-transferase, GST; acetylcholine esterase, AChE) of an ecologically relevant earthworm species (Lumbricus terrestris). GBHs and Als were applied at recommended doses; hand weeding served as control. Experiments were established with two soil types differing in organic matter content (SOM; $3.0 \%$ vs. $4.1 \%$ ) and other properties.
\end{abstract}

Results: Earthworm activity (casting and movement activity) decreased after application of glyphosate formulations or active ingredients compared to hand weeding. We found no consistent pattern that formulations had either higher or lower effects on earthworm activity than their active ingredients; rather, differences were substance-specific. Earthworm activity was little affected by soil organic matter levels. Biomarkers remained unaffected by weed control types; GST but not AChE was decreased under high SOM. Water infiltration after a simulated heavy rainfall was interactively affected by weed control types and SOM. Leachate amount was higher after application of formulations than active ingredients and was higher under low SOM. Glyphosate concentrations in soil and leachate were strongly affected by application of formulations or active ingredients and varied with SOM (significant weed control type $x$ SOM interaction).

Conclusions: We found that both commercial formulations and pure active ingredients can influence earthworms with consequences on important soil functions. Glyphosate products showed increased, reduced or similar effects than pure glyphosate on particular soil functions; soil properties can substantially alter this. Especially at lower SOM, heavy rainfalls could lead to more glyphosate leaching into water bodies. A full disclosure of co-formulants would be necessary to further decipher their specific contributions to these inconsistent effects.

\footnotetext{
*Correspondence: johann.zaller@boku.ac.at

${ }^{1}$ Institute of Zoology, University of Natural Resources and Life Sciences

Vienna (BOKU), Gregor Mendel Straße 33, 1180 Vienna, Austria

Full list of author information is available at the end of the article
} in this article are included in the article's Creative Commons licence, unless indicated otherwise in a credit line to the material. If material is not included in the article's Creative Commons licence and your intended use is not permitted by statutory regulation or exceeds the permitted use, you will need to obtain permission directly from the copyright holder. To view a copy of this licence, visit http://creativeco mmons.org/licenses/by/4.0/. 
Keywords: Amaranthus retroflexus, Co-formulants, Ecosystem services, Herbicides, Humus content, Lumbricus terrestris, Non-target effects, Soil fauna, Soil functions, Weed control

\section{Background}

Glyphosate-based herbicides (GBHs) are the globally most widely used pesticides applied in many sectors of agriculture, forestry, landscape planning, municipalities, and in private gardens [1-3]. Several hundred GBHs are in use and it is estimated that about 825 million kilograms of the active ingredient (AI) glyphosate (N-phosphonomethyl-glycine) is globally used per year $[2,4]$. It is rarely acknowledged that the AI glyphosate is not a single chemical but rather used in various salt forms with different chemical, physical and toxicological properties: e.g., as ammonium, dimethylammonium, isopropylammonium, potassium or trimesium salt of glyphosate [1, 5]. In order to formulate the commercial GBHs a multitude of co-formulants is added to these AIs for instance to improve the adhesion at the plant surface or to facilitate the intrusion into the target plant [1]. These co-formulants are considered inert although many AIs are only fully effective with these substances in the formulation.

Studies have shown that herbicide formulations can be differently effective against weeds [6] and non-target organisms than the mere AIs [7-12]. The proportion of co-formulants in GBH can reach up to $20 \%$ and GBHs toxic effects and endocrine disrupting properties were mostly due to the co-formulants even at concentrations much lower than used in practice $[13,14]$. Therefore, in the European Union, environmental risk assessments for pesticide approval include the testing of AIs of potential side-effects on non-target species and of at least one lead formulation depending on its characteristic and usage according to standard guidelines $[15,16]$. However, it is difficult to evaluate whether these risk assessments adequately assess non-target effects of the various products in use since the ingredients of commercial pesticides are considered as confidential business information and not declared.

After GBH application glyphosate residues remain in the soil with a half-life ranging from 2 to 215 days [17], depending on soil biological properties, the content of soil organic matter (SOM) and nutrients, or climatic factors [18-20]. Glyphosate residues (and its metabolites) can detrimentally influence crops, non-target plants and other organisms and the long half-life period is a concern [21]. In boreal soils $19 \%$ of the applied glyphosate was found even 20 months after the application; most glyphosate came into the soil via plant roots [22,23]. Glyphosate and its metabolite aminomethylphosphonic acid (AMPA) are among the most commonly found pesticide residues in soils [24-26] and water bodies around the world [2, $17,27-30]$. In aquatic systems glyphosate residues can affect the growth of algae and development of amphibians [31-33].

Earthworms (Lumbricidae) constitute the majority of soil faunal biomass in many temperate agroecosystems with up to 1000 individuals and $300 \mathrm{~g}$ of biomass in each square metre of land $[34,35]$. They modulate agroecosystem function by affecting nutrient cycling and decomposing organic material [36, 37], recovering soil carbon pools after disturbance [38], maintaining soil microbial diversity [39, 40], controlling plant pathogens [41-43], influencing water infiltration, and interacting with above ground organisms [44-47]. Thus, any herbicide-induced effect on earthworm activity will impact these ecosystem functions and influence water infiltration, and the binding and leaching of glyphosate [48].

Glyphosate has been shown to cause acute and chronic toxicological effects on a variety of animals [49]. Most studies on earthworms have been conducted using single glyphosate AIs or GBHs and only a few compared commercial GBHs with their respective AIs [50]. Earthworms of the species Eisenia fetida in soil contaminated with GBH residues (Roundup Ready-to-Use III, Roundup Super Concentrate) show less body mass decline and stress than those living in soil contaminated with the AI (glyphosate isopropylammonium salt) or in uncontaminated soil [51]. Others found that neither herbicide products (Spasor and Stam Novel Flo 480) nor their corresponding AIs (glyphosate and propanil) affected earthworm avoidance behaviour of E. andrei [52]. Other not glyphosate herbicides showed similar impacts on earthworms (E. andrei) for one product-AI pair (Mikado vs. AI sulcotrione), but higher toxicity of the other product-AI pair (Viper vs. AI penoxsulam) [53]. An excellent overview of earthworm studies dealing with GBHs and/or AIs provides Pochron et al. 2019 [54]; authors conclude that inconsistent results across studies most likely arise from variations in methodological approaches and the use of different earthworm species.

Besides behavioural measures, also biomarkers have been used to assess the effect of pesticides on earthworms. Changes in the activity of antioxidant enzymes including superoxide dismutase and catalase were used [55-57]. Membrane bound glutathione S-transferase (GST) activity, a major metabolic enzyme that contributes to the detoxification and neutralization of pollutants, was significantly elevated in earthworms (Lumbriculus 
variegatus) exposed to Roundup Ultra [55]. Elevated activities of GST were also observed in three earthworm species (Alma millsoni, Eudrilus eugeniae and Libyodrilus violaceus) exposed to Roundup Alphée while acetylcholine esterase (AChE), a neurotransmitter inactivating enzyme affecting neurotransmission and muscular activities, was found to be insensitive to this herbicide [58].

To the best of our knowledge, so far, no study compared impacts of several GBHs and their respective AIs on ecologically relevant earthworm species and associated ecosystem functions under different soil conditions. Therefore, we conducted a greenhouse experiment with a model weed population to assess (i) the effects of three widely used commercial GBHs and their pure AIs on the activity and physiology of the anecic earthworm species Lumbricus terrestris, (ii) whether different soil properties alter these responses, and (iii) the fate of glyphosate in soil and water samples after simulating a heavy rainfall event. We hypothesized that both GBHs and AIs affect earthworms, but that GBH-effects will be stronger because they contain co-formulants that can be toxic to earthworms [13]. We expected to be able to explain potential changes in earthworm activity and physiology by altered biomarker activity. We further hypothesized that GBH/AI-induced changes in earthworm activity will influence water infiltration and the absorption of glyphosate in soil and leachate. Due to a higher absorption of glyphosate onto soil organic matter we expected to find higher glyphosate concentrations in soils and consequently less glyphosate in leachate under higher SOM. Earthworm activity was examined over four weeks and effects were expected to decrease over time.

\section{Materials and methods}

\section{Experimental design}

The study was conducted as a pot experiment in a greenhouse of the University of Natural Resources and Life Sciences, Vienna (BOKU), Austria, between 20 April and 9 July 2018. The two-factorial design included the factor weed control type and the factor soil organic matter (SOM) content. Weed control types consisted of three GBHs, three corresponding AIs and hand weeding as a control treatment (details below). Soil organic matter levels consisted of soil with 3.0\% (low SOM) and 4.1\% (high $\mathrm{SOM})$. Every treatment was replicated five times resulting in $((3 \mathrm{GBHs}+3 \mathrm{AIs}+1$ control $) \times 2$ SOM levels $) \times 5$ replicates $=$ total 70 pots.

We used plastic planting pots with a surface diameter of $31 \mathrm{~cm}$, a height of $23 \mathrm{~cm}$ and a volume of 17.41 . In order to prevent the earthworms from escaping, the bottom drainage holes of the pots were covered with a mosquito net (mesh size $1 \mathrm{~mm}$ ); the upper rim was extended with a $20 \mathrm{~cm}$ high transparent plastic barrier greased with plant based soft soap. During the course of the experiment, average air temperature in the greenhouse was $21.3 \pm 4.1^{\circ} \mathrm{C}$ at natural light conditions.

Topsoil $(0-10 \mathrm{~cm})$ was collected using a frontloader on a tractor either from a conventionally managed (low $\mathrm{SOM}$ ) or an organically managed (high SOM) field of the Research Farm of the University of Natural Resources and Life Sciences Vienna. Soil type was in both cases a calceric Chernozem [59] cultivated using common crop rotations following good agricultural practice. As a consequence of their historically different cultivation the two soil types did not only differ in their SOM, but also in their $\mathrm{P}$ and $\mathrm{K}$ contents, however for the sake of clarity we refer mainly as low and high SOM soils. Overall, these SOM levels also reflect the average situation in conventional and organic arable farms in the region. Low SOM soils had a SOM content of $3.0 \%, \mathrm{P}=73 \mathrm{mg} \mathrm{kg}^{-1}$, $\mathrm{K}=140 \mathrm{mg} \mathrm{kg}^{-1}$, $\mathrm{pH}\left(\mathrm{CaCl}_{2}\right)=7.7$; high SOM soils had a SOM content of $4.1 \%, \mathrm{P}=113 \mathrm{mg} \mathrm{kg}^{-1}, \mathrm{~K}=234 \mathrm{mg} \mathrm{kg}^{-1}$, $\mathrm{pH}\left(\mathrm{CaCl}_{2}\right)=7.7$. All soil properties were determined according to standard methods: SOM following [60], P and $\mathrm{K}$ following [61], $\mathrm{pH}$ following [62].

Soil was thoroughly mixed, sieved (mesh size $1 \mathrm{~cm}$ ) and equal amounts were filled in the respective pots. The experimental soil was not sterilized and contained original soil micro- and mesofauna. Arable soil with low SOM was treated with synthetic insecticides (AIs deltamethrin, pymetrozine) three years prior to soil sampling; no herbicides were applied on these fields for at least five years. Soils with high SOM were organically farmed for 25 years and not treated with synthetic insecticides or herbicides ever since.

Amaranthus retroflexus was used as a model weed population, because it is one of the most commonly occurring weeds in arable fields in the study area. To generate a plant cover, A. retroflexus was sown on 20 April 2018 in four rows about 6-7 cm apart from each other. Each pot received $0.3 \mathrm{~g}$ of seeds according to the sowing recommendations for $A$. retroflexus. Seeding material was provided by ATC-Austrian Technology Corporation $\mathrm{GmbH}$. Pots were irrigated with 0.21 pot $^{-1}$ of tap water on six days a week with a watering can.

As a bioindicator for possible non-target effects of GBH/AI applications we introduced three adult and clitellated Lumbricus terrestris earthworm specimens to each pot (mean body mass $5.00 \pm 1.22 \mathrm{~g}$ ). Earthworms were purchased in a shop for fishing supplies in Vienna and added to the mesocosms on 12th May (22 days after seeding). To provide extra food for earthworms, chopped hay $\left(0.5 \mathrm{~g} \mathrm{pot}^{-1}\right)$ was added to all pots once a week. Most earthworm studies on herbicide effects have been conducted using epigeic compost worms (Eisenia species) $[54,63,64]$ that is a surrogate species in environmental 


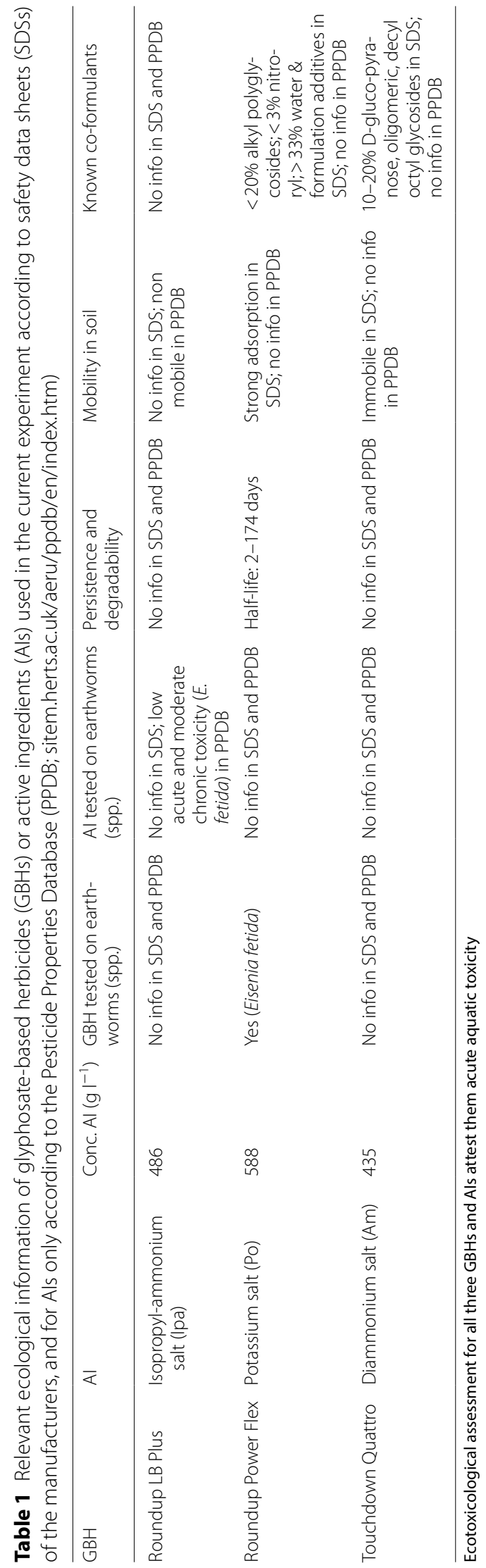


risk assessments $[65,66]$ but commonly do not inhabit agroecosystems. Here, we wanted to test GBH/AI effects on $L$. terrestris, an anecic species, that indeed inhabits arable fields $[41,67]$.

\section{Weed control types}

The GBH/AI treatments were applied on 13th June 2018 (54 days after seeding) onto A. retroflexus that had an average plant height of $22 \mathrm{~cm}$. The used GBHs (herbicide formulations) were: Roundup LB Plus (LB), Roundup PowerFlex (PF) (both products of Monsanto Agrar Deutschland $\mathrm{GmbH}$ ) and Touchdown Quattro (TQ) (a product of Syngenta Agro $\mathrm{GmbH}$ ), purchased at a local garden shop. Product information relevant for the current study according to the safety data sheets is provided in Table 1.

The corresponding AIs were salts of glyphosate: isopropylammonium salt (Ipa, AI of LB), potassium salt (Po, AI of PF) and diammonium salt (Am, AI of TQ). Glyphosate isopropylammonium salt was purchased from Toronto Research Chemicals (North York, Canada), while the potassium and diammonium salts were prepared and synthesized at the Agro-Environmental Research Centre, Institute of Environmental Sciences, Hungarian University of Agriculture and Life Sciences, Budapest, according to the procedures described previously [68]. The pastelike AIs were stirred in deionized water to make them applicable via a sprayer.

GBHs were applied once at recommended dosages just as they would be applied to kill weeds before sowing (psmregister.baes.gv.at): $51 \mathrm{ha}^{-1}$ for LB, $3.75 \mathrm{l} \mathrm{ha}^{-1}$ for $\mathrm{PF}$ and $5 \mathrm{l} \mathrm{ha}^{-1}$ for TQ. The dosages for the $\mathrm{AI}$ glyphosate salts were determined according to the concentration levels as given in the list of ingredients of the corresponding herbicide formulations. Different dosages recommended for the formulations resulted in a slightly different amount of glyphosate applied of 243, 221, $218 \mathrm{mg}$ a.i. $\mathrm{m}^{-2}$ for $\mathrm{LB}, \mathrm{PF}$ and TQ, respectively. These different dosages would also be applied in the field when recommendations are followed. Overall, we assumed that manufacturers gave their dosage recommendations in order to achieve the highest efficacy for their product while posing the least harm for the environment and it is therefore appropriate to compare the GBHs and AIs among each other despite differences in application rates.

All substances were sprayed on plant leaves using spray bottles with brass pump mist nozzles; we used separate spray bottles for each treatment. At the time of application plants in the pots covered the soil surface and direct spray on the soil was avoided. Most of the plants died within 5 days after spraying. In control treatments plants were hand weeded (pulled out) and left on the soil surface; afterwards tap water was applied in equal amounts as for the GBH/AI treatments.

\section{Measurements \\ Determination of earthworm activity and biomarkers (GST and AChE activity)}

Earthworm activity was assessed once a week by taking two measures of surface activity. First, casts deposited on the soil surface were collected during 4 weeks before and 4 weeks after GBH/AI application, counted, dried for $48 \mathrm{~h}$ at $50{ }^{\circ} \mathrm{C}$ and weighed. Earthworm activity was based on number and mass of casts produced per sampling event for the period before and after application of weed control type. Second, earthworm surface movement activity was assessed using the toothpick method [69]. Therefore, 10 wooden toothpicks mesocosm ${ }^{-1}$ were slightly inserted in a uniform pattern into the soil surface in a vertical position in the evening. Then, in the following morning the number of inclined or knocked-over toothpicks was counted. Activity was categorized according to the position of toothpicks: not disturbed (0 score), inclined ( 0.5 score), knocked-over ( 1 score). The category values were multiplied with the number of toothpicks in the respective category, summed up and used as a measure for earthworm surface activity.

Physiological reaction of earthworms to weed control treatments were assessed by measuring activities of the glutathione S-transferase (GST) and acetylcholine esterase (AChE) enzymes, as commonly used biomarkers. Chemicals used for the assays were obtained from Sigma-Aldrich Kft. (Budapest, Hungary): 1-chloro2,4-dinitrobenzene (CDNB), 5,5'-dithiobis-2-nitrobenzoic acid (DTNB), acetylthiocholine iodide, L-glutathione (reduced form), Bradford Reagent, bovine serum albumin (BSA), sodium hydrogen carbonate. All chemicals were of the highest commercially available grade.

At the end of the experiment ( 26 days after GHB/AI treatment) the survived adult and juvenile earthworms were collected by flipping over the pots; the collected earthworms were immediately frozen at $-20{ }^{\circ} \mathrm{C}$ and delivered to Hungary, where the samples were kept at $-80{ }^{\circ} \mathrm{C}$ until sample preparation. One adult earthworm from three randomly selected pots per treatment was weighed individually after the rinse and wiping process; thus three earthworms were used in enzymatic assays for GBHs and AIs. There were too few juvenile specimens to analyse. Weighed samples were added (1:2 w/v ratio) to ice cold sodium phosphate buffer $(0.1 \mathrm{M}, \mathrm{pH}$ 7.2) and homogenized in ice using an T10 basic UltraTurrax (IKA - Werke GmbH \& Co. KG, Staufen, Germany) at 15,000 rpm for $30 \mathrm{~s}, 20,000 \mathrm{rpm}$ for $30 \mathrm{~s}$ and at $25,000 \mathrm{rpm}$ for $30 \mathrm{~s} .200 \mathrm{mg}$ of homogenized sample was added to pre-cooled Eppendorf tubes with $800 \mu$ ice cold 
sodium phosphate buffer $(0.1 \mathrm{M}, \mathrm{pH} 7.2)$ resulted in the recommended $1: 10 \mathrm{w} / \mathrm{v}$ ratio $[70,71]$. The homogenates were kept at $-80{ }^{\circ} \mathrm{C}$ until usage, then were centrifuged for $30 \mathrm{~min}$ at $12,000 \times \mathrm{g}$ and $4{ }^{\circ} \mathrm{C} .450 \mu \mathrm{l}$ of the supernatants were transferred into pre-cooled LoBind microcentrifuge tubes and stored on ice until the measurement of enzyme activities. AChE and GST activities were measured in 3 replicates sample ${ }^{-1}$. The activity of enzymes was calculated from the slope of the absorbance curve and expressed as $\mu \mathrm{M}$ of formed product minute $\mathrm{mg}^{-1}$ protein, therefore prior the enzymatic assays protein concentrations of samples were determined in duplicates by the Bradford method [72] using BSA as a protein standard.

GST activity was determined using microtiter plates [73]. Enzymatic assays were performed in a reaction mixture containing $10 \mathrm{mM} \mathrm{L}$-glutathione (reduced form) (GSH) and $10 \mathrm{mM} \mathrm{CDNB}$ as a substrate in potassium phosphate buffer $(0.1 \mathrm{M}, \mathrm{pH}$ 6.5). For the determination of GST activity $10 \mu \mathrm{l}$ of the supernatant and $240 \mu \mathrm{l}$ of the reaction mixture were added to the wells of the precooled microtiter plate. Blanks were achieved under the same conditions, but the sample was replaced by buffer. The reaction was followed spectrophotometrically using a VICTOR 2 multilabel plate reader (PerkinElmer, USA) at $340 \mathrm{~nm}$ and $25^{\circ} \mathrm{C}$ for $3 \mathrm{~min}$ at every $15 \mathrm{~s}$. GST activity was expressed in $\mu \mathrm{M}$ of conjugated GSH min ${ }^{-1} \mathrm{mg}^{-1}$ protein.

AChE activity in each sample was measured according to the method of [74] and adapted to 96 well microtiter plates [75]. During the determination acetylthiocholine iodide was used as substrate. The reaction mixture was prepared in sodium phosphate buffer $(0.1 \mathrm{M}, \mathrm{pH} 7.2)$ containing $0.5 \mathrm{mM}$ DTNB and $7.5 \mathrm{mM}$ acetylthiocholine iodide and was kept in dark due to photosensitivity. For the determination of AChE activity $10 \mu \mathrm{l}$ of supernatant and $240 \mu \mathrm{l}$ of reaction mixture were added to the wells of the pre-cooled microtiter plate. The reaction was followed spectrophotometrically on a VICTOR 2 multilabel plate reader (PerkinElmer, USA) at $405 \mathrm{~nm}$ and $25^{\circ} \mathrm{C}$ for $3 \mathrm{~min}$ at every $15 \mathrm{~s}$. The reaction mixture without samples was used as blank. AChE activity was expressed in $\mu$ moles of hydrolysed acetylcholine iodide $\mathrm{min}^{-1} \mathrm{mg}^{-1}$ protein.

\section{Soil parameters, water infiltration, glyphosate concentrations in soil and water, plant harvest}

Soil temperature, moisture and electrical conductivity were measured two times a week using time domain reflectometry (TDR; IMKO HD2, with calibration 01-universal, and the moisture sensor TRIME-PICO, Ettlingen, Germany). Place markers in the centre of the mesocosms were kept in position to avoid injuring earthworms when inserting the TDR sensor fork.

At the end of the experiment (9th July 2018), we simulated a heavy rainfall event by pouring three litres of tap water $\left(39.7 \mathrm{l} \mathrm{m}^{-2}\right)$ on the surface of the experimental pots using a watering can with a sprinkler and measured the time needed for complete infiltration of the water. Water leaching out of the experimental pots was collected in pot saucers, volume measured and frozen at $-20^{\circ} \mathrm{C}$ until further analysis.

Degradation and accumulation of glyphosate were measured in soil samples, collected over the course of the experiment (22nd June, 4 July and 9 July 2018) using a soil core sampler ( $1 \mathrm{~cm}$ diameter, $5 \mathrm{~cm}$ depth), by HPLC analysis at the Agro-Environmental Research Centre in Budapest, Hungary. Prior to HPLC analysis the soil samples were prepared in five steps. First, $5 \mathrm{~g}$ air-dried soil was extracted $\left(25 \mathrm{ml}\right.$ of $0.03 \mathrm{~mol} \mathrm{l}^{-1}$ phosphate, $0.01 \mathrm{~mol} \mathrm{l}^{-1}$ citrate buffer), by using $30 \mathrm{~min}$ ultrasound agitation and the phases were separated by 10 min centrifugation at $3000 \mathrm{rpm}$. Ten $\mathrm{ml}$ of the supernatant was derivatized in the second step by adding $0.9 \mathrm{ml}$ of $130 \mathrm{mM}$ borate buffer $(\mathrm{pH}=9)$ and $0.3 \mathrm{ml}$ of $10 \mathrm{mM} \mathrm{FMOC-Cl}$ reagent. Solutions were homogenized by shaking and vortex, then kept for $2 \mathrm{~h}$ at room temperature in the dark. Third, removal of derivatizing agent was carried out by extraction of FMOC-Cl with $2 \times 3 \mathrm{ml}$ diethyl ether, 5 min centrifugation at $3000 \mathrm{rpm}$ between extractions and removal of organic phase. Fourth, set $\mathrm{pH}=3$ with $\mathrm{HCl}$ solution. Fifth, the aqueous phase was subjected to solid phase extraction (SPE) to concentrate the samples. Cartridges (Strata-X sorbent, $33 \mu \mathrm{m}, 200 \mathrm{mg}, 3 \mathrm{ml}$; Phenomenex) were conditioned $\left(5 \mathrm{ml}\right.$ of $\mathrm{MeOH}, 5 \mathrm{ml}$ of $2 x \mathrm{~d} . \mathrm{H}_{2} \mathrm{O}, 5 \mathrm{ml}$ of $50 \mathrm{mM}$ phosphate buffer at $\mathrm{pH} 3$ ), then samples were loaded followed by washing ( $3 \mathrm{ml}$ of $2 x d . \mathrm{H}_{2} \mathrm{O}$ ), 2-3 min drying, and elution with $5 \mathrm{ml}$ of $\mathrm{MeOH}$. The eluates were evaporated to dryness and re-solved in $0.5 \mathrm{ml}$ of the initial HPLC eluent.

Concentrations of glyphosate in leachate were determined at the Agro-Environmental Research Centre in Budapest, Hungary, by applying the HPLC method reported earlier [76]. Briefly, glyphosate was separated on a C18 column (Kinetex Core Shell, Phenomenex, $150 \mathrm{~mm} \times 4.6 \mathrm{~mm}$, i.d., $5 \mu \mathrm{m})$ at $40{ }^{\circ} \mathrm{C}$ and UV detector signals were recorded at $\lambda=260 \mathrm{~nm}$. The eluent flow rate was $0.7 \mathrm{~mL} \mathrm{~min}^{-1}$ with gradient elution. Initially, the eluent consisted of a 1:9 mixture of $A: B$ eluents $(A=100 \%$ $\mathrm{ACN}, \mathrm{B}=10 \mathrm{mM}$ aqueous sodium acetate buffer, $\mathrm{pH}=6$ ) that was gradually increased to $90 \% \mathrm{~A}$ at $6 \mathrm{~min}$ and maintained for $3 \mathrm{~min}$. Prior to HPLC analysis the water samples were prepared following the steps $2-5$ as described above for the preparation of the soil samples, starting with $10 \mathrm{ml}$ water samples. 
At the end of the experiment (26 days after applying the treatments), A. retroflexus biomass in the pots was separated in dead and green biomass; biomass was dried at $55^{\circ} \mathrm{C}$ for 5 days and weighed afterwards.

\section{Statistical analyses}

Statistical analyses were conducted with the software $R$ version 4.0.3 (The $\mathrm{R}$ Foundation for Statistical Computing; http://www.R-project.org) using the packages car [77] and multcomp [78]. Our statistical approach was to first perform analyses testing effects of weed control types (GBHs, AIs, hand weeding) and secondly to perform more detailed analyses among individual substances in order to assess differences between individual GBHs and their AIs. When the main treatment effects were significant, post-hoc comparisons were performed. We used type II tests for the analysis of variance or deviance to cope for possible imbalances.

Pre-treatment period: to examine possible differences in experimental units prior to application of weed control types effects on cast numbers and surface activity over a period of 4 weeks were tested using a generalized linear model (GLM) and analysis of deviance with quasiPoisson distribution with the factors weed control type (3 levels: GBHs, AIs and control) and SOM (2 levels: 3.0\% vs. $4.1 \% \mathrm{SOM}$ ) and their interactions; effects on cast mass production were analysed using a linear model (LM) and ANOVAs with Gaussian distribution using the same factors. Time, soil moisture, temperature and electrical conductivity were included as covariates in both models. Multiple comparisons (Tukey) were performed when main effects were significant $(\mathrm{p}<0.05)$.

Treatment period ( 4 weeks): analyses were performed in a similar manner as described above. First, analyses
(GLMs or LMs) considered weed control type (GBHs, AIs, control), SOM and their interactions; secondly more detailed analyses considering individual substances were performed. Time was included as covariate for earthworm activity parameters (4 sampling dates) and glyphosate in soil (3 sampling dates). Additional covariates included in the statistical models were soil moisture, temperature and conductivity. Treatment effects of onetime measured parameters AChE, GST, infiltration time, leachate amount and glyphosate in water were analysed using LMs and ANOVAs; for glyphosate in soil, time was additionally used as covariate to account for the three measurement dates. For both analyses post-hoc comparisons (Tukey) were made as simultaneous tests for general linear hypotheses but only performed when main effects were significant $(\mathrm{p}<0.05)$.

\section{Results}

\section{Pre-treatment conditions and efficacy of weed control}

Earthworm activity (number and mass of casts, surface movement) in the period before application of weed control types was similar in experimental units that were later assigned to particular treatments and not influenced by SOM levels (Table 2). Cast mass produced and surface activity but not cast numbers during the pre-treatment period varied with time; cast numbers and cast mass were positively influenced by the covariate soil temperature.

At the end of the experiment, aboveground plant material was collected. Proportion of green biomass was significantly influenced by weed control types but not by SOM levels. Across SOM, hand weeding showed the highest efficacy for weed control at a dry mass basis with $2 \pm 6 \%$ green biomass remaining at the end of the

Table 2 Pre-treatment period: earthworm activity in pots that were assigned to weed control type (WCT: glyphosate-based herbicides, active ingredients, or hand weeding as control) at two soil organic matter levels (SOM)

\begin{tabular}{|c|c|c|c|c|c|c|c|c|c|}
\hline \multirow[t]{2}{*}{ Factors } & \multicolumn{3}{|c|}{$\begin{array}{l}\text { Mean cast numbers } \\
\left(\text { no. } \text { pot }^{-1}\right)\end{array}$} & \multicolumn{3}{|c|}{$\begin{array}{l}\text { Mean cast mass } \\
\left(\mathrm{g} \mathrm{pot}^{-1}\right)\end{array}$} & \multicolumn{3}{|c|}{$\begin{array}{l}\text { Mean surface activity } \\
\text { (toothpick index) }\end{array}$} \\
\hline & Df & $\operatorname{LR} X^{2}$ & $\operatorname{Pr}\left(>X^{2}\right)$ & Df & Fvalue & $\operatorname{Pr}(>F)$ & Df & $\operatorname{LR} X^{2}$ & $\begin{array}{l}\operatorname{Pr} \\
\left(>X^{2}\right)\end{array}$ \\
\hline Weed control type & 2 & 1.021 & 0.600 & 2 & 1.429 & 0.241 & 2 & 0.264 & 0.876 \\
\hline SOM & 1 & 0.138 & 0.710 & 1 & 0.089 & 0.766 & 1 & 0.357 & 0.550 \\
\hline Covar. time & 1 & 0.215 & 0.643 & 1 & 24.727 & $<0.001$ & 1 & 7.690 & 0.006 \\
\hline Covar. soil moist. (\%) & 1 & 0.092 & 0.761 & 1 & 0.953 & 0.330 & 1 & 0.213 & 0.644 \\
\hline Covar. soil temp. $\left({ }^{\circ} \mathrm{C}\right)$ & 1 & 17.163 & $<0.001$ & 1 & 25.075 & $<0.001$ & 1 & 0.688 & 0.407 \\
\hline Covar soil cond. $\left(\mathrm{mS} \mathrm{m}^{-1}\right)$ & 1 & 0.198 & 0.657 & 1 & 0.649 & 0.421 & 1 & 0.592 & 0.442 \\
\hline WCT $\times$ SOM & 2 & 0.092 & 0.955 & 2 & 0.311 & 0.733 & 2 & 0.133 & 0.936 \\
\hline Residuals & NA & & & 261 & & & NA & & \\
\hline
\end{tabular}

GLMs/analysis of deviance was used for cast numbers and surface activity, LM/ANOVA for cast mass; time period (4 weeks), soil moisture, temperature and electrical conductivity was used as covariates. Significant treatment effects are indicated in bold. NA not applicable. No multiple comparisons were made because of lacking main effects 
experiment, while $32 \pm 13 \%$ green mass was found after GBH treatment and $51 \pm 25 \%$ after AIs. More details on the efficacy of weed control types on plants are reported elsewhere [68].

\section{Treatment effects on earthworm activity}

Cast numbers and surface movement activity was affected by weed control types (GBHs, AIs, control), but not by SOM levels (Table 3; Fig. 1). Cast numbers were significantly lower after GBH or AI application than after hand weeding; GBHs and AIs showed similar effects on cast numbers (Table 3). Surface movement activity was significantly lower after GBH or AI application than after hand weeding; effects of GBH and AI were similar (Table 3). Cast mass was unaffected by weed control types or SOM.

Comparing effects of individual treatments it was seen that cast numbers (Fig. 1a, b) and surface movement (Fig. 1e, f) were significantly affected by weed control types while cast mass remained unaffected (Fig. 1c, d). SOM level had no effect on individual measures, however cast numbers were significantly affect by a weed control type $\mathrm{x}$ SOM interaction. Post-hoc comparisons between GBH-AI pairs revealed no significant results.

\section{Biomarkers GST and AChE in earthworms}

Activity of biomarkers in earthworm tissue was unaffected by weed control types (Table 4). However, GST across weed control types was significantly lower under higher SOM levels; AChE was unaffected by SOM (Table 4).

\section{Water infiltration and leachate}

Water infiltration was significantly affected by weed control types, SOM and their interactions (Table 5; Fig. 2). Comparisons between weed control types showed that water infiltration was significantly lower after $\mathrm{GBH}$ or AI application than after hand weeding, but there was no difference between GBHs and respective AIs (Table 5; Fig. 2a, b). Multiple comparisons of GBH-AI pairs showed no significant difference for water infiltration but a significant weed control type $\mathrm{x}$ SOM interaction with less infiltration under high SOM (Fig. 2a, b).

Leachate amount was also significantly affected by weed control types and SOM, but without an interactive effect (Table 5; Fig. 2). Comparisons between weed control types showed a significant difference between GBHs and AIs but not between GBH or AI and control (Table 5). Multiple comparisons of individual GBH-AI pairs showed no effects (Fig. 2c, d).

\section{Glyphosate concentration in soil and leachate}

Both glyphosate concentrations in soil (Fig. 3a, b) and leachate (Fig. 3c, d) were highly significantly affected by weed control types and their interactions (Table 5). Only glyphosate in water was additionally affected by SOM

Table 3 After-treatment period: earthworm activity in response to weed control types (WCT: glyphosate-based herbicides GBH, active ingredients Al, or hand weeding as control) and soil organic matter levels (SOM). GLM/analysis of deviance was used for cast numbers and surface activity, LM/ANOVA for cast mass; time period (4 weeks), soil moisture, temperature and electrical conductivity was used as covariates

\begin{tabular}{|c|c|c|c|c|c|c|c|c|c|}
\hline \multirow[t]{2}{*}{ Factors } & \multicolumn{3}{|c|}{ Mean cast numbers (no. pot ${ }^{-1}$ ) } & \multicolumn{3}{|c|}{ Mean cast mass $\left(\mathrm{g} \mathrm{pot}^{-1}\right)$} & \multicolumn{3}{|c|}{ Mean surface activity (toothpick index) } \\
\hline & $\overline{\mathrm{Df}}$ & $\mathrm{LR} X^{2}$ & $\operatorname{Pr}\left(>X^{2}\right)$ & Df & Fvalue & $\operatorname{Pr}(>F)$ & $\overline{D f}$ & $\mathrm{LR} X^{2}$ & $\operatorname{Pr}\left(>X^{2}\right)$ \\
\hline Weed control type & 2 & 7.558 & 0.023 & 2 & 2.213 & 0.120 & 2 & 11.533 & 0.003 \\
\hline SOM & 1 & 0.421 & 0.517 & 1 & 0.000 & 0.996 & 1 & 0.667 & 0.414 \\
\hline Covar. time & 1 & 1.075 & 0.300 & 1 & 0.004 & 0.952 & 1 & 0.221 & 0.638 \\
\hline Covar. soil moist. (\%) & 1 & 11.291 & 0.001 & 1 & 0.000 & 0.986 & 1 & 5.154 & 0.023 \\
\hline Covar. soil temp. $\left({ }^{\circ} \mathrm{C}\right)$ & 1 & 0.052 & 0.819 & 1 & 0.000 & 0.998 & 1 & 8.417 & 0.004 \\
\hline Covar. soil cond. $\left(\mathrm{mS} \mathrm{m}^{-1}\right)$ & 1 & 0.054 & 0.816 & 1 & 0.156 & 0.694 & 1 & 0.749 & 0.387 \\
\hline WCT x SOM & 2 & 0.905 & 0.636 & 2 & 1.042 & 0.360 & 2 & 1.281 & 0.527 \\
\hline \multirow[t]{2}{*}{ Residuals } & NA & & & 261 & & & NA & & \\
\hline & z value & \multicolumn{2}{|l|}{$\operatorname{Pr}(>|z|)$} & t value & \multicolumn{2}{|c|}{$\operatorname{Pr}(>t)$} & \multicolumn{2}{|r|}{ z value } & $\operatorname{Pr}(>|z|)$ \\
\hline \multicolumn{10}{|c|}{ Multiple comparisons of means (Tukey) } \\
\hline $\mathrm{Al}$ - control & -2.188 & \multicolumn{2}{|l|}{0.073} & NA & \multicolumn{2}{|c|}{ NA } & \multicolumn{2}{|r|}{-2.822} & 0.013 \\
\hline $\mathrm{GBH}$ - control & -2.838 & \multicolumn{2}{|l|}{0.013} & NA & \multicolumn{2}{|c|}{ NA } & \multicolumn{2}{|r|}{-3.498} & 0.001 \\
\hline $\mathrm{GBH}-\mathrm{Al}$ & -0.688 & \multicolumn{2}{|l|}{0.771} & NA & \multicolumn{2}{|c|}{ NA } & & -0.693 & 0.768 \\
\hline
\end{tabular}

Significant treatment effects are indicated in bold. No multiple comparisons were performed for cast mass because of lacking main effects NA not applicable 


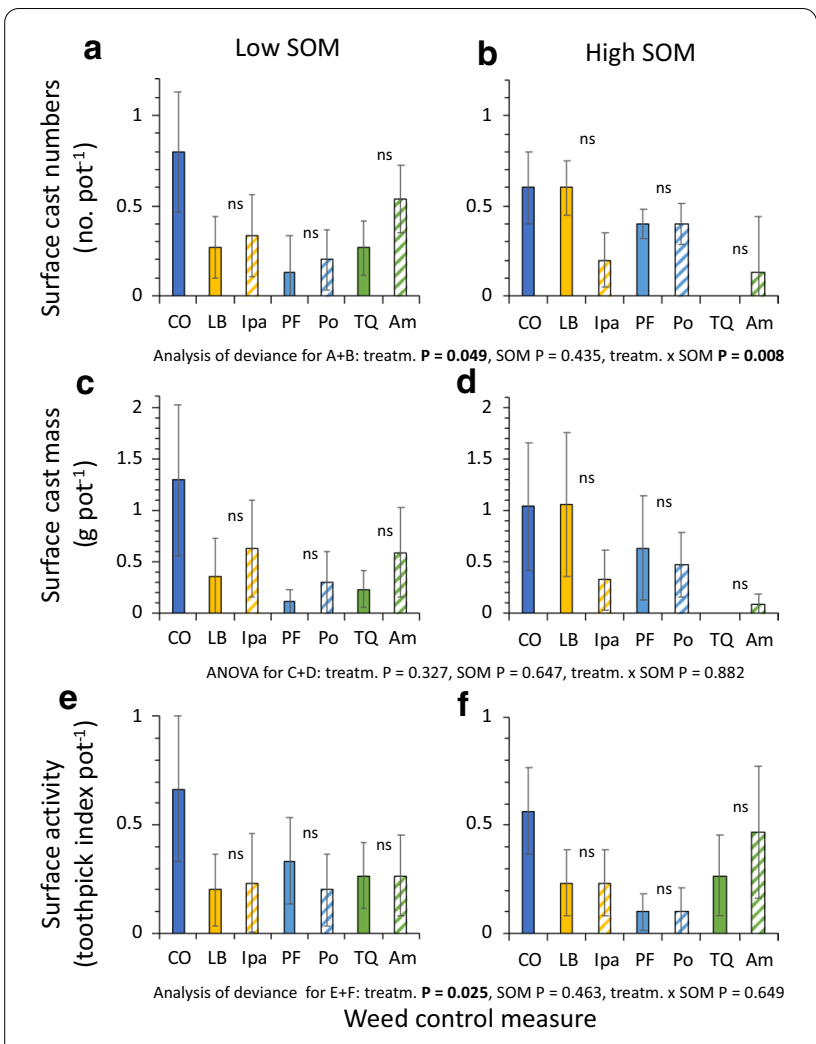

Fig. 1 Mean surface cast numbers $(\mathbf{a}, \mathbf{b})$, cast mass $(\mathbf{c}, \mathbf{d})$ and surface movement activity $(\mathbf{e}, \mathbf{f})$ in response to hand weeding (CO), or chemical weed control with glyphosate-based herbicides (LBRoundup LB, PF-Roundup PowerFlex, TQ-Touchdown Quattro) or their respective active ingredients (Ipa-isopropylammonium salt, Po—potassium salt, Am—diammonium salt) under low (a, c, e) and high (b, d, f) soil organic matter (SOM) levels. Statistical results from analyses of deviance and ANOVAs on individual treatments are given below panels; subsequent Tukey tests compared GBH-Al pairs. Significant results in bold; ns not significantly different ( $p>0.05$ ). Means \pm SE across a 4-week sampling period, $n=5$

with higher concentrations under low SOM. Comparisons between weed control types showed significantly more glyphosate in soil and water under GBH than control, significantly higher glyphosate in soil under AI than control and significantly more glyphosate in water under GBHs than AIs (Table 5). Multiple comparisons of individual treatments showed significantly higher glyphosate concentrations in water under LB compared to its AI Ipa and between TQ and its AI Am at low SOM (Fig. 3c), while all other GBH-AI pairs were similar (Fig. $3 \mathrm{a}-\mathrm{c}$ ).

\section{Discussion}

We studied the impacts of three commercial glyphosate formulations and their respective pure glyphosate active ingredients on earthworms and soil parameters under two soil organic matter levels. Understanding such interactions is important for more realistic ecotoxicological assessments [48, 69, 79]. We found a decreased surface activity of earthworms after GBHs or AIs compared to hand weeding but no influence of SOM. Earthworm activity was similarly affected by GBHs and AIs and weed control types had no influence on biomarkers. Both leachate and glyphosate concentrations in water were significantly higher under GBHs than under AIs. SOM levels significantly affected GST biomarker activity in earthworms, water infiltration and leaching as well as glyphosate concentrations in water. Of particular importance were interactions between weed control types and SOM because they indicate that effects are soil-type specificity, an aspect that is commonly not considered in environmental risk assessments. Below, these effects will be discussed in more details.

\section{Effects on earthworms}

We expected to see different effects between GBHs and AIs because additional co-formulants in GBHs might have detrimental effects on earthworms [13]. However, our findings showed no consistent difference between effects on earthworm activity of the group of GBHs compared to the group of AIs. Also, we could not confirm findings that glyphosate (isopropylamine salt) is more harmful than the respective GBHs (Roundup Ready-toUse III, Roundup Super Concentrate) [51]. In our experiment all treatments left dead plant material as food on the soil surface. Thus, we explain a reduced earthworm activity after GBH or AI application compared to hand weeding as an avoidance of glyphosate contaminated leaf material on the soil surface. Further, this difference might be due to (i) known detrimental effects of GBHs and AIs on earthworm activity [48, 51, 54, 69, 80, 81], (ii) a slightly higher soil moisture in control pots as a result of a higher weed control efficacy of hand weeding as compared to GBH/AI applications and thus lower plant transpiration $[48,82]$. Another explanation might be that dying roots after GBH/AI application provided a food source for earthworms belowground which shifted their activity from aboveground to belowground [83]. Earthworm activity was assessed over four weeks but we found no indication that effects would decrease with time. Others have shown that earthworms (E. fetida) can recover from effects of GBHs (Roundup Ready-to-Use III) after three weeks [84].

Although earthworm activity (cast numbers, surface activity) was significantly affected by GBHs and AIs, multiple comparisons of individual GBHs and AIs showed no significant differences. This is mainly due to complex interactions with SOM levels indicating that impacts of GBHs and AIs depend on soil properties. Effects of GBHs were in some cases higher, in others lower than effects of the respective AIs. The only 
Table 4 Biomarkers (acetylcholine esterase AChE, glutathione S-transferase GST) in earthworms in response to weed control types (WCT: glyphosate-based herbicides GBHs, active ingredients Als, hand weeding as control) at different soil organic matter (SOM) levels (low 3.0\%, high 4.1\%)

\begin{tabular}{|c|c|c|c|c|c|c|}
\hline Weed control type & \multicolumn{3}{|c|}{ soM level } & \multicolumn{2}{|l|}{$\begin{array}{l}\text { AChE activity } \\
\mu \mathrm{Mol} \mathrm{min}^{-1} \mathrm{mg}^{-1}\end{array}$} & $\begin{array}{l}\text { GST activity } \\
\mu \mathrm{Mol} \mathrm{min}^{-1} \mathrm{mg}^{-1}\end{array}$ \\
\hline $\mathrm{GBH}$ & \multicolumn{2}{|c|}{ Low } & & \multicolumn{2}{|l|}{$523.54 \pm 98.48$} & $463.27 \pm 115.13$ \\
\hline $\mathrm{Al}$ & & & & \multicolumn{2}{|l|}{$565.59 \pm 95.99$} & $469.79 \pm 69.67$ \\
\hline Control & & & & \multicolumn{2}{|l|}{$603.37 \pm 159.65$} & $446.99 \pm 74.24$ \\
\hline GBH & \multicolumn{2}{|c|}{ High } & & \multicolumn{2}{|l|}{$521.79 \pm 127.42$} & $366.87 \pm 105.26$ \\
\hline Al & & & & \multicolumn{2}{|l|}{$463.18 \pm 86.69$} & $396.90 \pm 127.49$ \\
\hline Control & & & & \multicolumn{2}{|l|}{$499.76 \pm 9.09$} & \multirow[t]{2}{*}{$398.99 \pm 50.48$} \\
\hline ANOVA results & & & & & & \\
\hline \multirow[t]{2}{*}{ Factors } & \multicolumn{3}{|c|}{ AChE activity } & & \multicolumn{2}{|c|}{ GST activity } \\
\hline & Df & Fvalue & $\operatorname{Pr}(>\mathrm{F})$ & Df & F value & $\operatorname{Pr}(>F)$ \\
\hline Weed control type & 2 & 0.385 & 0.683 & 2 & 0.152 & 0.860 \\
\hline SOM & 1 & 3.071 & 0.088 & 1 & 6.209 & 0.017 \\
\hline $\mathrm{WCT} \times \mathrm{SOM}$ & 2 & 1.115 & 0.339 & 2 & 0.132 & 0.877 \\
\hline Residuals & 36 & & & 36 & & \\
\hline
\end{tabular}

Means $\pm S D, n=15$ for $\mathrm{GBH}$ and $\mathrm{Al} ; \mathrm{n}=5$ for control. Significant results in bold. No multiple comparisons were made because of lacking main effects

consistent pattern across GBHs and AIs was that after GBHs/AIs application earthworm activity was in the majority of cases lower and never higher than after hand weeding. Our observations also confirm earlier findings that different agrochemicals affect different parameters in earthworms [85].

In contrast to our current findings are results from other experiments, where no short-term effects of GBHs on the activity (and growth) of L. terrestris was observed, e.g., for the product Rodeo XL with $360 \mathrm{~g} \mathrm{l}^{-1}$ [86] or for Roundup Power Flex with $588 \mathrm{~g} \mathrm{l}^{-1}$ both with potassium salt as AIs [87]. However, it was also shown that GBHs (Roundup Ready-to-Use III, Roundup Super Concentrate) were actually less harmful for earthworms (E. fetida) than pure isopropylamine glyphosate salt [51]. Unfortunately, a further exploration of underlying mechanisms is precluded by the concealment of the complete list of ingredients of the studied GBHs. Studies show that co-formulants in GBHs were cytotoxic and endocrine disrupting well below the doses used in agriculture [14]. It is suggested that glyphosate is only slightly toxic to plants at the recommended doses in agriculture and most of the phytotoxic effect of GBHs come from the co-formulants including the heavy metals arsenic, chromium, cobalt, lead and nickel which are known to be endocrine disruptors and also toxic to animals [13]. A lower phytotoxicity of the AIs compared to the GBHs could also be confirmed in a previous study using the same setting as in the current one [68].
These inconsistent results across studies are difficult to interpret but most likely arise from variations in tested application rates, differences in compared formulations and glyphosate salts, different assessments of earthworm activity and different earthworm species investigated [54]. Our current findings showed that additionally soil properties play an important interactive role. Moreover, earthworm responses to GBH or AI can also vary with intrinsic worm characteristics such as the initial body mass and that their stress reaction against herbicides can be higher at cooler temperatures [54]. In our study surface movement activity was affected by soil temperature (as covariate) with decreased activity with increased temperature. However, when comparing these findings it is important to note that different parameters were assessed and the former study [54] was conducted with a different earthworm species (E. fetida) that is most likely differently susceptible to herbicides and temperature than L. terrestris in our experiment [88]. In previous studies we also found species-specific responses of earthworms to herbicides. In one study the activity of the anecic $L$. terrestris was reduced after GBH application while the soil-dwelling species $A$. caliginosa remained almost unaffected [48]. In field studies a lack of earthworm response to GBH treatment might also be the result of only those species or individuals remaining that were adapted to year-long pesticide applications [87, 89]. Another issue are legacy effects of previous herbicide treatments that might have interfered with actual applications. However, this is unlikely in our study as low SOM soils did 
Table 5 ANOVA results testing effects of weed control types (WCT: glyphosate-based herbicides GBHs, their active ingredients Als, or hand weeding as control) and soil organic matter level (SOM) on water infiltration rate and leachate, and glyphosate concentrations in soil and water

\begin{tabular}{|c|c|c|c|c|c|c|}
\hline \multirow[t]{3}{*}{ Factors } & \multicolumn{6}{|c|}{ Measurement parameters } \\
\hline & \multicolumn{3}{|c|}{ Water infiltration rate $\left(\mathrm{mm} \mathrm{min}^{-1}\right)$} & \multicolumn{3}{|c|}{ Water leachate $\left(\mid \mathrm{m}^{-2}\right)$} \\
\hline & Df & F value & $\operatorname{Pr}(>F)$ & Df & Fvalue & $\operatorname{Pr}(>F)$ \\
\hline Weed control type & 2 & 4.725 & 0.012 & 2 & 4.996 & 0.010 \\
\hline SOM & 1 & 45.991 & $<0.001$ & 1 & 28.072 & $<0.001$ \\
\hline WCT $\times$ SOM & 2 & 5.935 & 0.004 & 2 & 1.279 & 0.285 \\
\hline \multirow[t]{2}{*}{ Residuals } & \multicolumn{3}{|l|}{64} & \multicolumn{3}{|l|}{64} \\
\hline & & $t$ value & $\operatorname{Pr}(>|t|)$ & & t value & $\operatorname{Pr}(>|t|)$ \\
\hline \multicolumn{7}{|c|}{ Multiple comparisons of means (Tukey) } \\
\hline Al-Control & & 3.006 & 0.010 & & 2.268 & 0.066 \\
\hline GBH-Control & & -2.680 & 0.024 & & -0.245 & 0.967 \\
\hline \multirow[t]{3}{*}{$\mathrm{GBH}-\mathrm{Al}$} & & 0.461 & 0.888 & & 2.861 & 0.015 \\
\hline & \multicolumn{3}{|c|}{ Glyphosate conc. in soil (ng g-1) } & \multicolumn{3}{|c|}{ Glyphosate conc. in water (ng g-1) } \\
\hline & Df & Fvalue & $\operatorname{Pr}(>F)$ & Df & Fvalue & $\operatorname{Pr}(>F)$ \\
\hline Weed control type & 2 & 5.910 & 0.003 & 2 & 11.317 & $<0.001$ \\
\hline SOM & 1 & 2.745 & 0.099 & 1 & 22.144 & $<0.001$ \\
\hline Time & 1 & 52.727 & $<0.001$ & NA & NA & NA \\
\hline WCT $\times$ SOM & 2 & 7.242 & 0.001 & 2 & 4.163 & 0.020 \\
\hline \multirow[t]{2}{*}{ Residuals } & 200 & & & 62 & & \\
\hline & & $t$ value & $\operatorname{Pr}(>|t|)$ & & t value & $\operatorname{Pr}(>|t|)$ \\
\hline \multicolumn{7}{|c|}{ Multiple comparisons of means (Tukey) } \\
\hline Al-Control & & -3.135 & 0.006 & & -1.549 & 0.269 \\
\hline GBH-Control & & 3.317 & 0.003 & & 4.049 & $<0.001$ \\
\hline $\mathrm{GBH}-\mathrm{Al}$ & & 0.269 & 0.960 & & 3.953 & $<0.001$ \\
\hline
\end{tabular}

See Figs. 2, 3 for illustrations of these effects. Significant treatment effects are in bold

NA not applicable

not receive GBH treatments at least in the previous three years and high SOM soils were under organic cultivation for 25 years without any herbicide application ever since. Glyphosate concentrations in control soils of our current experiment were below detection levels.

Besides earthworms, comparisons between GBHs and their AIs have rarely been studied on other soil animals [49]. A study testing the same GBHs and AIs on springtails (soil mesofauna) shows increased surface activity of springtails both under GBHs and AIs compared to hand weeding with a higher stimulation of springtail activity under higher SOM levels [68]. Another study found only minor effects of GBHs (Roundup Gold, $450 \mathrm{~g} \mathrm{l}^{-1}$ potassium salt) on enchytraeids and nematodes [90].

The lack of response of the biomarkers GST and AChE to GBH and AI applications indicated no altered physiological response of earthworms to GBH or AI is confirmed by findings of others [54-57]. However, because we analysed GST and AChE only 26 days after GBH/AI application we might have missed the strongest biochemical response. Others indeed found an inhibition of GST in the endogeic earthworm Octolasion cyaneum 28 days after a commercial GBH (Atanor SCA; AI potassium salt) was applied [56]. The lack of response in AChE is in accordance with the information in the safety data sheets of Roundup LB Plus and Roundup Power Flex mentioning that the products are not AChE inhibitors. Our findings suggested that Touchdown Quattro also does not appear to be an AChE inhibitor. However, more specific studies would be necessary to confirm this.

Comparing biomarker studies further confirms that different earthworm species respond differently to different GBHs: in the three earthworm species (Alma millsoni, Eudrilus eugeniae and Libyodrilus violaceus) higher activities of GST were observed after GBH (Roundup Alphée; isopropylammonium salt of glyphosate as AI) application while no response on $\mathrm{AChE}$ activity was seen [58]. Overall, the application of various pesticides have 


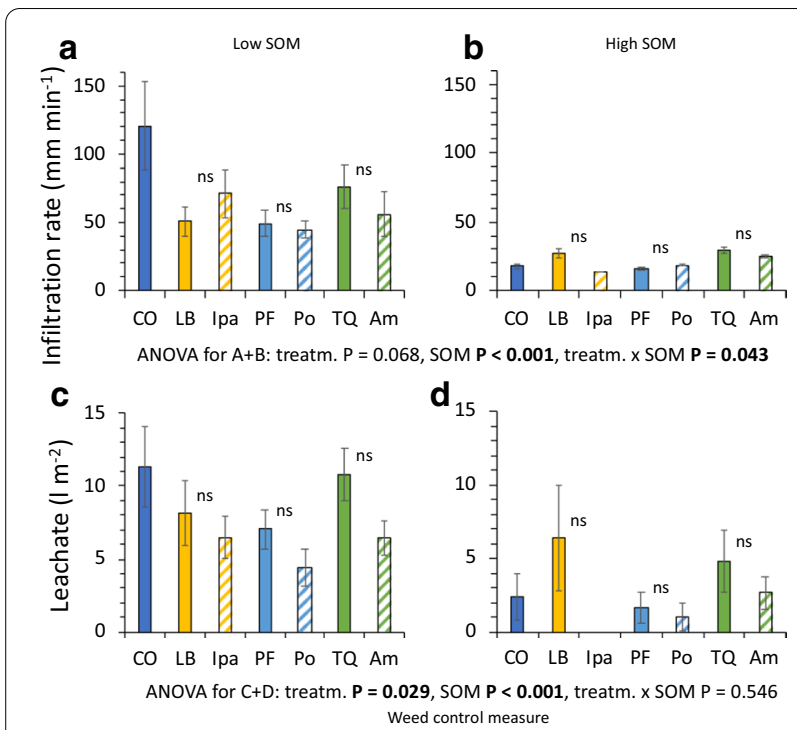

Fig. 2 Mean water infiltration rate $(\mathbf{a}, \mathbf{b})$ and leachate amount $(\mathbf{c}, \mathbf{d})$ after a simulated heavy rainfall in response to hand weeding (CO), or chemical weed control with glyphosate-based herbicides (LBRoundup LB, PF - Roundup PowerFlex, Touchdown Quattro-TQ) or their respective active ingredients (Ipa-isopropylammonium salt, Po-potassium salt, Am—diammonium salt) under low $(\mathbf{a}, \mathbf{c})$ and high (b, d) soil organic matter (SOM) levels. Statistical results from ANOVAs are given below panels; Tukey tests compared GBH-Al pairs. $n$ not significantly different $(p>0.05)$. Means $\pm S E, n=5$

been shown to reduce $\mathrm{AChE}$ activities in earthworms (Allolobophora chlorotica) in apple orchards [91].

\section{Water infiltration, leaching and glyphosate in soil and leachate}

After simulating a heavy rainfall event with $40 \mathrm{~mm}$, we found that the water infiltration rate and leachate amount were affected by both GBH/AI application and SOM. We interpret this as a consequence of GBH/AI effects on earthworm burrowing activity and consequences for soil hydrology [44, 48, 92, 93]. A higher water infiltration at lower SOM can be attributed to lower water-holding capacities in soils with less organic matter [94]. It was interesting to see that water infiltration under low SOM was twice as high than under high SOM (significant herbicide x SOM interaction) although SOM levels of the two soil types only differed by $1.1 \%$ (relative difference in SOM between soil types 36\%). More detailed studies would be needed to examine whether there is a tipping point in SOM effects on infiltration. As direct effects of GBH or AI on SOM are not plausible we believe that herbicide interactions with SOM are mediated by earthworms. Anecic earthworm species, such as L. terrestris studied here, form permanent and stable burrows that are important for

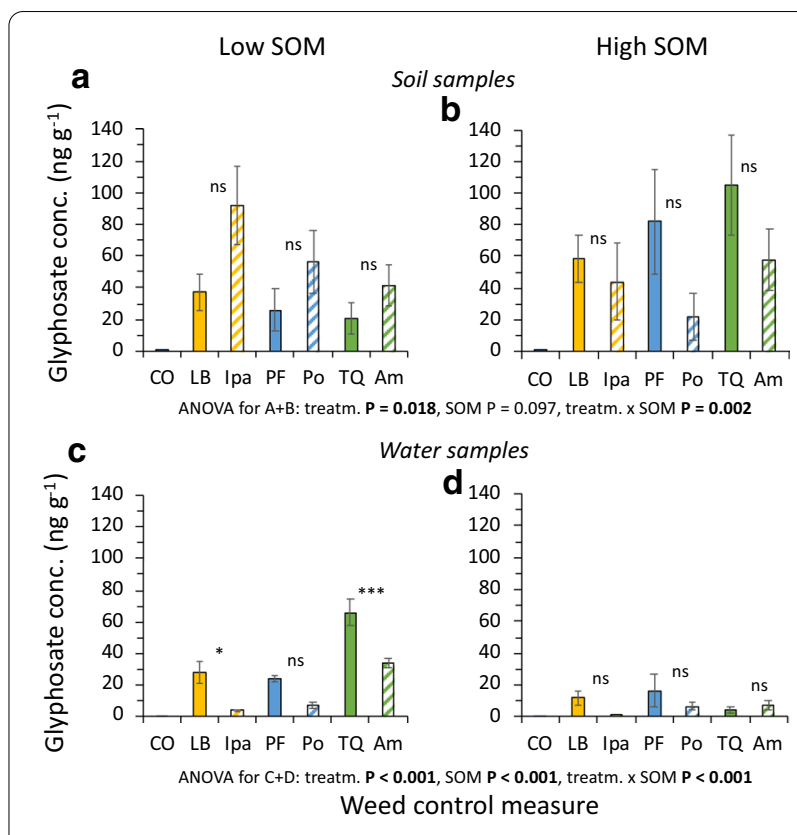

Fig. 3 Mean glyphosate concentrations in soil $(\mathbf{a}, \mathbf{b})$ and leachate (c, d) after a simulated heavy rainfall in response to hand weeding (CO), or chemical weed control with glyphosate-based herbicides (LBRoundup LB, PF-Roundup PowerFlex, TQ-Touchdown Quattro) or their respective active ingredients (Ipa-isopropylammonium salt, Po_- potassium salt, Am—diammonium salt) under low (a, c) and high (b, d) soil organic matter (SOM) levels. Statistical results from ANOVAs are given below panels; Tukey tests compared GBH-Al pairs. Significant effects in bold; $n s$ not significantly different $(p>0.05)$, ${ }^{*} p<0.05,{ }^{* *} p<0.001$. Means $\pm S E, n=5$

water infiltration and soil aeration [95] and earthworm activity has been shown to affect glyphosate leaching [69].

When heavy rainfalls become more prevalent under climate change [96] a higher infiltration would be beneficial after heavy rainfalls. However, a higher infiltration might also increase glyphosate leaching. Indeed, we found that both GBH and AI application strongly increased glyphosate concentrations in soil and leachate and both parameters were highly influenced by a herbicide $\mathrm{x}$ SOM interaction. Generally, after GBH application twice as high glyphosate concentrations were found in soils at high SOM than at low SOM. Contrastingly, after AI application lower glyphosate concentrations were found at high SOM than at low SOM. Sorption and degradation of glyphosate depends on various environmental conditions like microbial activity, temperature, soil moisture, $\mathrm{pH}$ and soil minerals [97], and in our experiment regular watering most likely increased the degradation of glyphosate in the soil $[98,99]$. More detailed studies would be necessary to reveal the underlying mechanisms also regarding the interaction with soil biological activity and chemistry. 
The current study focused only on responses to a one-time GBH/AI application and we cannot predict long-term consequences. Glyphosate is commonly considered to easily degrade with an estimated half-life of 2-215 days depending on soil types and environmental factors [17]. Others found that 19\% of the applied amount of glyphosate was present in the topsoil even 20 months after its application [22, 23]. These results indicate rather long persistence for glyphosate (at least in boreal soils) and that residues might affect earthworms over a longer time. To what extent such residues affect earthworm population dynamics or whether glyphosate is bioaccumulated or biomagnified by earthworms remains to be studied [58]. Our analyses were conducted 26 days after GBH/AI applications and indicate that substantial amounts of glyphosate are still available in soils especially under high SOM $\left(82 \pm 23 \mu \mathrm{g} \mathrm{kg}{ }^{-1}\right.$ across GBHs, $41 \pm 18 \mu \mathrm{g} \mathrm{kg}^{-1}$ across AIs) and would thus be prone to leaching. Glyphosate residues have been found in topsoils across Europe and $45 \%$ of the soils contained $>50 \mu \mathrm{g} \mathrm{kg}^{-1}$ [100]. In Argentina, due to intensive cultivation of glyphosate-tolerant genetically modified crops glyphosate was almost ubiquitous in soils with very high concentrations up to $8105 \mu \mathrm{g} \mathrm{kg}$ [101]. Experimental results show that $88 \%$ of the applied glyphosate was retained in the upper 0-9 $\mathrm{cm}$ surface soil layer, but that glyphosate residues were also found down to $1 \mathrm{~m}$ soil depth [102].

We also found considerable amounts of glyphosate in leachate (up to $66 \mu \mathrm{ll}^{-1}$ under low SOM) with interactive effects between weed control types and SOM. At low SOM glyphosate concentrations in leachate was $41 \%$ higher under GBHs but $76 \%$ lower under AIs compared to glyphosate concentrations in the soil. In contrast, at high SOM glyphosate concentrations in leachate was $87 \%$ lower under GBHs and $88 \%$ lower under AIs than glyphosate in the soil. This finding indicated that co-formulants in GBH might have influenced the mobility of AI in the soilwater interface. To elucidate the underlying mechanisms including biological and chemical interactions it would be necessary to know the exact ingredients of the GBHs. Studies confirm that glyphosate leaching is a problem. When rain falls shortly after GBH application, up to $47 \%$ of the applied glyphosate has been shown to be dissipated with surface run-off [103]. In a greenhouse pot study with field soil glyphosate was also easily leached with concentrations $>250 \mu \mathrm{g} \mathrm{l}^{-1}$ in leachate [69]. In Argentina areas of intensive glyphosate use, maximum glyphosate concentrations in surface water were $1.80 \mu \mathrm{g} \mathrm{l}^{-1}$ [101].

\section{Conclusions}

We found that both commercial glyphosate formulations and pure active ingredients can reduce earthworm activity compared to hand weeding, with cascading consequences for the fate of glyphosate in soil and leachate. Because water infiltration and glyphosate in soil and water were also interactively influenced by soil properties we suggest that relationships between formulations and active ingredients, earthworms and ecosystem functions are likely to be soil type specific. In order to fully understand the differential effects of formulations vs. their active ingredients a full disclosure of all ingredients in the formulations would be mandatory. Clearly, more investigations considering long-term effects at different trophic levels seem necessary for a more realistic evaluation of ecological side-effects of glyphosate herbicides.

\section{Acknowledgements}

We are grateful to the University of Natural Resources and Life Sciences Research Farm in Groß Enzersdorf for providing the soil, and to ATC Agro Trial Center-Gerhaus, Parndorf, Austria, for providing the A. retroflexus seed material. Suggestions and comments by anonymous reviewers helped to improve the manuscript.

\section{Authors' contributions}

ASz, ET, EG, JGZ planned and conceptualized the study; MW, MM conducted the experiments, JR provided ecotoxicological expert knowledge; BS, FL, JGZ performed statistical analyses; ET, MM, SK, ASz, and JGy synthesized Als and performed chemical and biochemical analyses; MW, JGZ wrote the first draft; JGZ made graphs; all authors reviewed the final manuscript.

\section{Funding}

This work was supported by a project (No. 97öu3) funded by the foundation action Austria-Hungary of the Osztrák-Magyar Akció Alapítvány (OMAA) and the Austrian Agency for International Cooperation in Education and Research (OED) granted to AS and JGZ. The funding body had no role in the design of the study and collection, analysis, and interpretation of data and in writing the manuscript.

Availability of data and materials

The datasets used and/or analysed during the current study are available from the corresponding author on reasonable request.

\section{Declarations}

Ethics approval and consent to participate

This study was approved by the ethics committee of the University of Natural Resources and Life Sciences, Vienna.

\section{Consent for publication}

Not applicable.

\section{Competing interests}

The authors declare that they have no competing interests.

\section{Author details}

${ }^{1}$ Institute of Zoology, University of Natural Resources and Life Sciences Vienna (BOKU), Gregor Mendel Straße 33, 1180 Vienna, Austria. ${ }^{2}$ Agro-Environmental Research Centre, Institute of Environmental Sciences, Hungarian University of Agriculture and Life Sciences, Herman Ottó út 15, 1022 Budapest, Hungary. 3 Balaton Limnological Research Institute, Eötvös Loránd Research Network (ELKH), Klebelsberg Kunó utca 3, 8237 Tihany, Hungary. ${ }^{4}$ ECT Oekotoxikologie GmbH, Böttgerstraße 2, 65439 Flörsheim, Germany. ${ }^{5}$ Institute of Statistics, University of Natural Resources and Life Sciences Vienna (BOKU), Peter-Jordan-Straße 82, 1190 Vienna, Austria. 
Received: 17 June 2020 Accepted: 7 April 2021

Published online: 20 April 2021

\section{References}

1. Székács A, Darvas B (2012) Forty years with glyphosate. In: Hasaneen MN (ed) Herbicides - properties, synthesis and control of weeds. InTech, Rijeka, pp 247-284. https://doi.org/10.5772/32491

2. Székács A, Darvas B (2018) Re-registration challenges of glyphosate in the European union. Front Environ Sci. https://doi.org/10.3389/fenvs. 2018.00078

3. Zaller JG (2020) Daily poison. Pesticides_an underestimated danger. Springer Nature, Cham. https://doi.org/10.1007/978-3-030-50530-1

4. Benbrook CM (2016) Trends in glyphosate herbicide use in the United States and globally. Env Sci Eur 28:3. https://doi.org/10.1186/ s12302-016-0070-0

5. Cuhra M, Bøhn T, Cuhra P (2016) Glyphosate: too much of a good thing? Front Environ Sci 4:28

6. Travlos I, Cheimona N, Bilalis D (2017) Glyphosate efficacy of different salt formulations and adjuvant additives on various weeds. Agronomy 7:60. https://doi.org/10.3390/agronomy7030060

7. Moore LJ, Fuentes L, Rodgers JH, Bowerman WW, Yarrow GK, Chao WY, Bridges WC (2012) Relative toxicity of the components of the original formulation of Roundup ${ }^{\circledR}$ to five North American anurans. Ecotoxicol Environ Saf 78:128-133. https://doi.org/10.1016/j.ecoenv.2011.11.025

8. Cuhra M, Bøhn T (2016) Glyphosate: too much of a good thing? Front Environ Sci 4:28

9. Mullin CA, Fine JD, Reynolds RD, Frazier MT (2016) Toxicological risks of agrochemical spray adjuvants: organosilicone surfactants may not be safe. Front Public Health 4:92. https://doi.org/10.3389/fpubh.2016. 00092

10. Mesnage R, Defarge N, Vendômois JSd, Séralini G-E (2014) Major pesticides are more toxic to human cells than their declared active principles. BioMed Res Int. https://doi.org/10.1155/2014/179691

11. Williams GM, Kroes R, Munro IC (2000) Safety evaluation and risk assessment of the herbicide roundup and its active ingredient, glyphosate, for humans. Regul Toxic Pharmacol 31:117-165. https://doi.org/10. 1006/rtph.1999.1371

12. Cox C, Surgan M (2006) Unidentified inert ingredients in pesticides: implications for human and environmental health. Env Health Perspec 114:1803-1806. https://doi.org/10.1289/ehp.9374

13. Defarge N, Spiroux de Vendômois J, Séralini GE (2018) Toxicity of formulants and heavy metals in glyphosate-based herbicides and other pesticides. Toxicol Rep 5:156-163. https://doi.org/10.1016/j.toxrep.2017. 12.025

14. Defarge N, Takács E, Lozano VL, Mesnage R, Vendômois JS, Seralini GE, Székács A (2016) Co-formulants in glyphosate-based herbicides disrupt aromatase activity in human cells below toxic levels. Int J Env Res Pub Health 13:264. https://doi.org/10.3390/ijerph13030264

15. Commission E (2013) Commission regulation (EU) No 284/2013 of 1 March 2013 setting out the data requirements for plant protection products, in accordance with Regulation (EC) No 1107/2009 of the European Parliament and of the Council concerning the placing of plant protection products on the market. Off J Eur Union L93:85-152

16. Commission E (2013) Commission regulation (EU) No 283/2013 of 1 March 2013 setting out the data requirements for active substances, in accordance with Regulation (EC) No 1107/2009 of the European Parliament and of the Council concerning the placing of plant protection products on the market. Off J Eur Union L93:1-84

17. Battaglin WA, Meyer MT, Kuivila KM, Dietze JE (2014) Glyphosate and its degradation product ampa occur frequently and widely in U.S. Soils, surface water, groundwater, and precipitation. J Am Water Res Assoc 50:275-290. https://doi.org/10.1111/jawr.12159

18. EFSA (2015) Conclusion on the peer review of the pesticide risk assessment of the active substance glyphosate. EFSA J 13:4302, 4107. https:// doi.org/10.2903/j.efsa.2015.4302

19. Albers CN, Banta GT, Hansen PE, Jacobsen OS (2009) The influence of organic matter on sorption and fate of glyphosate in soil-Comparing different soils and humic substances. Environ Poll 157:2865-2870. https://doi.org/10.1016/j.envpol.2009.04.004
20. Piccolo A, Celano G, Conte P (1996) Adsorption of glyphosate by humic substances. J Agric Food Chem 44:2442-2446. https://doi.org/10.1021/ jf950620x

21. Singh S, Kumar V, Datta S, Wani AB, Dhanjal DS, Romero R, Singh J (2020) Glyphosate uptake, translocation, resistance emergence in crops, analytical monitoring, toxicity and degradation: a review. Env Chem Lett 18:663-702. https://doi.org/10.1007/s10311-020-00969-z

22. Laitinen P, Ramo S, Nikunen U, Jauhiainen L, Siimes K, Turtola E (2009) Glyphosate and phosphorus leaching and residues in boreal sandy soil. Plant Soil 323:267-283

23. Laitinen P, Rämö S, Siimes K (2007) Glyphosate translocation from plants to soil—does this constitute a significant proportion of residues in soil? Plant Soil 300:51-60

24. Silva V, Montanarella L, Jones A, Fernández-Ugalde O, Mol HGJ, Ritsema CJ, Geissen V (2017) Distribution of glyphosate and aminomethylphosphonic acid (AMPA) in agricultural topsoils of the European Union. Sci Total Environ 621:1352-1359. https://doi.org/10.1016/j.scitotenv.2017. 10.093

25. Silva V, Mol HGJ, Zomer P, Tienstra M, Ritsema CJ, Geissen V (2019) Pesticide residues in European agricultural soils - a hidden reality unfolded. Sci Tot Environ 653:1532-1545. https://doi.org/10.1016/j.scitotenv.2018. 10.441

26. Maggi F, la Cecilia D, Tang FHM, McBratney A (2020) The global environmental hazard of glyphosate use. Sci Tot Environ 717:137167. https:// doi.org/10.1016/j.scitotenv.2020.137167

27. Borggaard OK, Gimsing AL (2008) Fate of glyphosate in soil and the possibility of leaching to ground and surface waters: a review. Pest Manag Sci 64:441-456

28. Coupe RH, Kalkhoff SJ, Capel PD, Gregoire C (2012) Fate and transport of glyphosate and aminomethylphosphonic acid in surface waters of agricultural basins. Pest Manag Sci. https://doi.org/10.1002/ps.2212

29. Malaj E et al (2014) Organic chemicals jeopardize the health of freshwater ecosystems on the continental scale. PNAS 111:9549-9554. https:// doi.org/10.1073/pnas.1321082111

30. Sabatier $\mathrm{P}$ et al (2014) Long-term relationships among pesticide applications, mobility, and soil erosion in a vineyard watershed. PNAS 111:15647-15652. https://doi.org/10.1073/pnas.1411512111

31. Baier F, Jedinger M, Gruber E, Zaller JG (2016) Temperature-dependence of glyphosate-based herbicide's effects on egg and tadpole growth of common toads. Front Environ Sci. https://doi.org/10.3389/fenvs.2016. 00051

32. Relyea RA (2005) The lethal impact of roundup on aquatic and terrestrial amphibians. Ecol Appl 15:1118-1124

33. Relyea RA, Jones DK (2009) The toxicity of Roundup Original Max ${ }^{\circledR}$ to 13 species of larval amphibians. Env Toxicol Chem 28:2004-2008. https:// doi.org/10.1897/09-021.1

34. Edwards CA, Bohlen PJ (1996) Biology and ecology of earthworms, 3rd edn. Chapman \& Hall, London

35. Curry JP (1994) Grassland invertebrates. Ecology, influence on soil fertility and effects on plant growth. Springer Netherlands, Dordrecht, NL

36. Creamer CA, de Menezes AB, Krull ES, Sanderman J, Newton-Walters R, Farrell M (2015) Microbial community structure mediates response of soil C decomposition to litter addition and warming. Soil Biol Biochem 80:175-188. https://doi.org/10.1016/j.soilbio.2014.10.008

37. Schimel J, Schaeffer S (2012) Microbial control over carbon cycling in soil. Front Microbiol. https://doi.org/10.3389/fmicb.2012.00348

38. Angst $\mathrm{G}$ et al (2019) Earthworms act as biochemical reactors to convert labile plant compounds into stabilized soil microbial necromass. Commun Biol 2:441. https://doi.org/10.1038/s42003-019-0684-z

39. Liu T et al (2019) Earthworms coordinate soil biota to improve multiple ecosystem functions. Curr Biol 29:3420-3429.e3425. https://doi.org/10. 1016/j.cub.2019.08.045

40. Liu M, Cao J, Wang C (2020) Bioremediation by earthworms on soil microbial diversity and partial nitrification processes in oxytetracyclinecontaminated soil. Ecotox Env Safety 189:109996. https://doi.org/10. 1016/j.ecoenv.2019.109996

41. Euteneuer P, Wagentristl H, Steinkellner S, Scheibreithner C, Zaller JG (2019) Earthworms affect decomposition of soil-borne plant pathogen Sclerotinia sclerotiorum in a cover crop field experiment. Appl Soil Ecol 138:88-93. https://doi.org/10.1016/j.apsoil.2019.02.020 
42. Li N, Wang C, Li X, Liu M (2019) Effects of earthworms and arbuscular mycorrhizal fungi on preventing Fusarium oxysporum infection in the strawberry plant. Plant Soil 443:139-153. https://doi.org/10.1007/ s11104-019-04224-5

43. Plaas E et al (2019) Towards valuation of biodiversity in agricultural soils: a case for earthworms. Ecol Econ 159:291-300. https://doi.org/10. 1016/j.ecolecon.2019.02.003

44. Zaller JG et al (2011) Earthworm-mycorrhiza interactions can affect the diversity, structure and functioning of establishing model grassland communities. PLOS ONE 6:e29293

45. Wurst S, Sonnemann I, Zaller JG (2018) Soil macro-invertebrates- their impact on plants and associated aboveground communities in temperate regions. In: Ohgushi T, Wurst S, Johnson SN (eds) Abovegroundbelowground community ecology, vol Ecological Studies 234. Springer, Tokyo, pp 175-200. https://doi.org/10.1007/978-3-319-91614-9

46. Hoeffner K, Monard C, Santonja M, Cluzeau D (2018) Feeding behaviour of epi-anecic earthworm species and their impacts on soil microbial communities. Soil Biol Biochem 125:1-9. https://doi.org/10.1016/j.soilb io.2018.06.017

47. Zhang B-G, Li G-T, Shen T-S, Wang J-K, Sun Z (2000) Changes in microbial biomass $C, N$, and $P$ and enzyme activities in soil incubated with the earthworms Metaphire guillelmi or Eisenia fetida. Soil Biol Biochem 32:2055-2062. https://doi.org/10.1016/S0038-0717(00)00111-5

48. Gaupp-Berghausen M, Hofer M, Rewald B, Zaller JG (2015) Glyphosatebased herbicides reduce the activity and reproduction of earthworms and lead to increased soil nutrient concentrations. Sci Rep 5:12886. https://doi.org/10.1038/srep12886

49. Gill JPK, Sethi N, Mohan A, Datta S, Girdhar M (2018) Glyphosate toxicity for animals. Env Chem Lett 16:401-426. https://doi.org/10.1007/ s10311-017-0689-0

50. Zaller JG, Brühl CA (2021) Direct herbicide effects on terrestrial nontarget organisms belowground and aboveground. In: Mesnage R, Zaller JG (eds) Herbicides. Chemistry, Efficacy, Toxicology, and Environmental Impacts. Elsevier, Amsterdam, ISBN 978-0-12-823674-1, pp 181-230

51. Pochron S, Simon L, Mirza A, Littleton A, Sahebzada F, Yudell M (2020) Glyphosate but not Roundup ${ }^{\circledR}$ harms earthworms (Eisenia fetida). Chemosphere 241:125017. https://doi.org/10.1016/j.chemosphere.2019. 125017

52. Pereira JL, Antunes SC, Castro BB, Marques CR, Goncalves AMM, Goncalves F, Pereira R (2009) Toxicity evaluation of three pesticides on non-target aquatic and soil organisms: commercial formulation versus active ingredient. Ecotoxicol 18:455-463. https://doi.org/10.1007/ s10646-009-0300-y

53. Marques C, Pereira R, Goncalves F (2009) Using earthworm avoidance behaviour to assess the toxicity of formulated herbicides and their active ingredients on natural soils. J Soils Sediments 9:137-147. https:// doi.org/10.1007/s11368-009-0058-0

54. Pochron S et al (2019) Temperature and body mass drive earthworm (Eisenia fetida) sensitivity to a popular glyphosate-based herbicide. Appl Soil Ecol 139:32-39. https://doi.org/10.1016/j.apsoil.2019.03.015

55. Contardo-Jara V, Klingelmann E, Wiegand C (2009) Bioaccumulation of glyphosate and its formulation Roundup Ultra in Lumbriculus variegatus and its effects on biotransformation and antioxidant enzymes. Environ Poll 157:57-63. https://doi.org/10.1016/j.envpol.2008.07.027

56. Salvio C, Menone ML, Rafael S, Iturburu FG, Manetti PL (2016) Survival, reproduction, avoidance behavior and oxidative stress biomarkers in the earthworm octolasion cyaneum exposed to glyphosate. Bull Environ Contamin Toxicol 96:314-319. https://doi.org/10.1007/ s00128-015-1700-8

57. Givaudan N, Binet F, Le Bot B, Wiegand C (2014) Earthworm tolerance to residual agricultural pesticide contamination: Field and experimental assessment of detoxification capabilities. Environ Poll 192:9-18. https:// doi.org/10.1016/j.envpol.2014.05.001

58. Owagboriaye F, Dedeke G, Bamidele J, Aladesida A, Isibor P, Feyisola R, Adeleke M (2020) Biochemical response and vermiremediation assessment of three earthworm species (Alma millsoni, Eudrilus eugeniae and Libyodrilus violaceus) in soil contaminated with a glyphosate-based herbicide. Ecol Ind 108:105678. https://doi.org/10.1016/j.ecolind.2019. 105678

59. WRB (2014) World Reference Base for Soil Resources. FAO, Rome, Italy
60. ÖNORM L1080 (2013) Chemische Bodenuntersuchungen - Bestimmung des organischen Kohlenstoffs durch trockene Verbrennung mit und ohne Berücksichtigung von Carbonaten.9pp

61. ÖNORM L1087 (2012) Chemical analysis of soils-Determination of "plant-available" phosphorus and potassium by the calcium-acetatelactate (CAL)-method. Austrian Standards, p 11

62. ÖNORM EN15933 (2012) Schlamm, behandelter Bioabfall und Boden-Bestimmung des pH-Werts. Austrian Standards:1100

63. Wang YH, Wu SG, Chen LP, Wu CX, Yu RX, Wang Q, Zhao XP (2012) Toxicity assessment of 45 pesticides to the epigeic earthworm Eisenia fetida. Chemosphere 88:484-491. https://doi.org/10.1016/j.chemo sphere.2012.02.086

64. Yasmin S, D'Souza D (2007) Effect of pesticides on the reproductive output of Eisenia fetida. Bull Environ Contamin Toxicol 79:529-532. https://doi.org/10.1007/s00128-007-9269-5

65. OECD (2004) Guidelines for testing of chemicals. 222: earthworm reproduction test (Eisenia fetida/Eisenia andrei). Organisation for Economic Cooperation and Development, Paris

66. OECD (2004) OECD Guidelines for the Testing of Chemicals 222: Earthworm Reproduction Test (Eisenia fetida / Eisenia andrei).

67. Stroud JL et al (2017) Cover cropping with oilseed radish (Raphanus sativus) alone does not enhance deep burrowing earthworm (Lumbricus terrestris) midden counts. Soil Till Res 165:11-15. https://doi. org/10.1016/j.still.2016.07.013

68. Maderthaner M et al (2020) Commercial glyphosate-based herbicides effects on springtails (Collembola) differ from those of their respective active ingredients and vary with soil organic matter content. Env Sci Poll Res 27:17280-17289. https://doi.org/10.1007/ s11356-020-08213-5

69. Zaller JG, Heigl F, Ruess L, Grabmaier A (2014) Glyphosate herbicide affects belowground interactions between earthworms and symbiotic mycorrhizal fungi in a model ecosystem. Sci Rep 4:5634. https:// doi.org/10.1038/srep05634

70. González Vejares S, Sabat P, Sanchez-Hernandez JC (2010) Tissuespecific inhibition and recovery of esterase activities in Lumbricus terrestris experimentally exposed to chlorpyrifos. Comp Biochem Physiol C 151:351-359. https://doi.org/10.1016/j.cbpc.2009.12.008

71. Martínez Morcillo S, Yela JL, Capowiez Y, Mazzia C, Rault M, SanchezHernandez JC (2013) Avoidance behaviour response and esterase inhibition in the earthworm, Lumbricus terrestris, after exposure to chlorpyrifos. Ecotoxicol 22:597-607. https://doi.org/10.1007/s10646-013-1051-3

72. Bradford MM (1976) A rapid and sensitive method for the quantitation of microgram quantities of protein utilizing the principle of protein-dye binding. Analyt Biochem 72:248-254. https://doi.org/10.1016/00032697(76)90527-3

73. Habig WH, Pabst MJ, Jakoby WB (1974) Glutathione S-transferases. The first enzymatic step in mercapturic acid formation. J Biol Chem 249:7130-7139

74. Ellman GL, Courtney KD, Andres V, Featherstone RM (1961) A new and rapid colorimetric determination of acetylcholinesterase activity. Biochem Pharmacol 7:88-95. https://doi.org/10.1016/0006-2952(61) 90145-9

75. Hamers T, Molin KRJ, Koeman JH, Murk AJ (2000) A small-volume bioassay for quantification of the esterase inhibiting potency of mixtures of organophosphate and carbamate insecticides in rainwater: development and optimization. Toxicol Sci 58:60-67. https://doi.org/10.1093/ toxsci/58.1.60

76. Klátyik S et al (2017) Dissipation of the herbicide active ingredient glyphosate in natural water samples in the presence of biofilms. Int J Env Analyt 97:901-921. https://doi.org/10.1080/03067319.2017.13737 70

77. Fox J, Weisberg S (2019) An R companion to applied regression, 3rd edn. Sage Publications, Thousand Oaks, CA

78. Hothorn T, Bretz F, Westfall P (2008) Simultaneous inference in general parametric models. Biometr J 50:346-363

79. Vereecken $\mathrm{H}$ (2005) Mobility and leaching of glyphosate: a review. Pest Manag Sci 61:1139-1151. https://doi.org/10.1002/ps.1122

80. Pelosi C, Barot S, Capowiez Y, Hedde M, Vandenbulcke F (2014) Pesticides and earthworms. A review. Agron Sustain Dev 34:199-228

81. van Hoesel W et al (2017) Single and combined effects of pesticide seed dressings and herbicides on earthworms, soil microorganisms, 
and litter decomposition. Front Plant Sci 8:215. https://doi.org/10.3389/ fpls.2017.00215

82. Hurtalová T, Usowicz B, Kossowski J, Matejka F (2001) Effect of plant cover on soil water content and seasonal changes in evapotranspiration. Contr Geophys Geodesy 31:467-476

83. Arnone JA, Zaller JG (2014) Earthworm effects on native grassland root system dynamics under natural and increased rainfall. Front Plant Sci 5:152. https://doi.org/10.3389/fpls.2014.00152

84. Pochron ST et al (2021) Earthworms Eisenia fetida recover from Roundup exposure. Appl Soil Ecol 158:103793. https://doi.org/10. 1016/j.apsoil.2020.103793

85. Van Gestel CAM, Dirven-Van Breemen EM, Baerselman R, Emans HJB, Janssen JAM, Postuma R, Van Vliet PJM (1992) Comparison of subletha and lethal criteria for nine different chemicals in standardized toxicity tests using the earthworm Eisenia andrei. Ecotox Env Safety 23:206-220. https://doi.org/10.1016/0147-6513(92)90059-C

86. Nuutinen V, Hagner M, Jalli H, Jauhiainen L, Rämö S, Sarikka I, UusiKämppä J (2020) Glyphosate spraying and earthworm Lumbricus terrestris L. activity: Evaluating short-term impact in a glasshouse experiment simulating cereal post-harvest. Eur J Soil Biol 96:103148. https:// doi.org/10.1016/j.ejsobi.2019.103148

87. Zaller JG et al (2018) Herbicides in vineyards reduce grapevine root mycorrhization and alter soil microorganisms and the nutrient composition in grapevine roots, leaves, xylem sap and grape juice. Env Sci Poll Res 25:23215-23226. https://doi.org/10.1007/s11356-018-2422-3

88. Pelosi C, Joimel S, Makowski D (2013) Searching for a more sensitive earthworm species to be used in pesticide homologation tests-a meta-analysis. Chemosphere 90:895-900. https://doi.org/10.1016/j. chemosphere.2012.09.034

89. Stellin F, Gavinelli F, Stevanato P, Concheri G, Squartini A, Paoletti MG (2017) Effects of different concentrations of glyphosate (Roundup360 ${ }^{\circledR}$ ) on earthworms (Octodrilus complanatus, Lumbricus terrestris and Aporrectodea caliginosa) in vineyards in the North-East of Italy. Appl Soil Ecol. doi: https://doi.org/10.1016/j.apsoil.2017.07.028

90. Hagner M, Mikola J, Saloniemi I, Saikkonen K, Helander M (2019) Effects of a glyphosate-based herbicide on soil animal trophic groups and associated ecosystem functioning in a northern agricultural field. Sci Rep 9:13. https://doi.org/10.1038/s41598-019-44988-5

91. Denoyelle R, Rault M, Mazzia C, Mascle O, Capowiez Y (2007) Cholinesterase activity as a biomarker of pesticide exposure in Allolobophora chlorotica earthworms living in apple orchards under different management strategies. Env Toxicol Chem 26:2644-2649. https://doi.org/ 10.1897/06-355.1

92. Ernst G, Felten D, Vohland M, Emmerling C (2009) Impact of ecologically different earthworm species on soil water characteristics. Eur J Soil Biol 45:207-213

93. Shipitalo MJ, Nuutinen V, Butt KR (2004) Interaction of earthworm burrows and cracks in a clayey, subsurface-drained, soil. Appl Soil Ecol 26:209-217. https://doi.org/10.1016/j.apsoil.2004.01.004
94. Bordoloi R, Das B, Yam G, Pandey P, Tripathi O (2019) Modeling of water holding capacity using readily available soil characteristics. Agric Res 8:347-355. https://doi.org/10.1007/s40003-018-0376-9

95. Altmeier J, Schobel S, Emmerling C (2002) Beitrag von Regenwürmern zum Infiltrations- und Abflussgeschehen in Böden in Abhängigkeit von Bodensubstrat und Bodennutzung. Mitt Deutsch Bodenkundl Ges 99:177-178

96. IPCC, et al (eds) (2012) Managing the risks of extreme events and disasters to advance climate change adaptation. Cambridge University Press, Cambridge

97. Henderson AM et al. (2010) Glyphosate technical fact sheet. http://npic orst.edu/factsheets/archive/glyphotech.html. Accessed 27 Aug 2019

98. Capri E, Vicari A (2010) Environmental fate and behaviour of glyphosate and its main metabolite. European Glyphosate Environmental Information Source http://www.egeis-toolbox.org/documents/10\%20Fate\% 20and\%20behaviour\%20v3.2.pdf:3pp

99. Schroll R, Becher HH, Dörfler U, Gayler S, Grundmann S, Hartmann HP, Ruoss J (2006) Quantifying the effect of soil moisture on the aerobic microbial mineralization of selected pesticides in different soils. Env Sci Technol 40:3305-3312. https://doi.org/10.1021/es052205j

100. Silva V, Montanarella L, Jones A, Fernandez-Ugalde O, Mol HGJ, Ritsema CJ, Geissen V (2018) Distribution of glyphosate and aminomethylphosphonic acid (AMPA) in agricultural topsoils of the European Union. Sci Tot Environ 621:1352-1359. https://doi.org/10.1016/j.scitotenv.2017.10. 093

101. Primost JE, Marino DJG, Aparicio VC, Costa JL, Carriquiriborde P (2017) Glyphosate and AMPA, "pseudo-persistent" pollutants under real-world agricultural management practices in the Mesopotamic Pampas agroecosystem, Argentina. Environ Poll 229:771-779. https://doi.org/10, 1016/j.envpol.2017.06.006

102. Lupi L, Bedmar F, Puricelli M, Marino D, Aparicio VC, Wunderlin D, Miglioranza KSB (2019) Glyphosate runoff and its occurrence in rainwater and subsurface soil in the nearby area of agricultural fields in Argentina. Chemosphere 225:906-914. https://doi.org/10.1016/j.chemo sphere.2019.03.090

103. Todorovic GR, Rampazzo N, Mentler A, Blum WEH, Eder A, Strauss P (2014) Influence of soil tillage and erosion on the dispersion of glyphosate and aminomethylphosphonic acid in agricultural soils. Int Agrophysics 28:93-100

\section{Publisher's Note}

Springer Nature remains neutral with regard to jurisdictional claims in published maps and institutional affiliations.

\section{Submit your manuscript to a SpringerOpen ${ }^{\odot}$ journal and benefit from:}

- Convenient online submission

- Rigorous peer review

- Open access: articles freely available online

- High visibility within the field

- Retaining the copyright to your article

Submit your next manuscript at $\boldsymbol{\nabla}$ springeropen.com 